\title{
リグニンの発生について（そのニ）
}

小林晃夫訳

\section{Zur Biogenese des Lignins!}

Von Karl Kratzl

\section{高等植物における芳香環の形成}

こうして芳香核をるった Coniferylalkohol が与え られると、それがリグニンに移行していくことが知ら れたが，次いで更にリグニンの芳香核の基礎骨格の形 成に関する研究すなされている。すなわらまず Neish

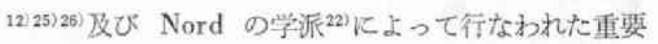
な予借研究がある。彼等の研究により, Shikimisäure はリグニンを生じるということが分った。例えば特別 にマークした Shikimisäure (2，6 をマーク) は2, 6るマークされたリグニンを生成し，このリグニンを 分解寸ると 2, 6をマークされた Vanillin を与え る24。バクテリアの生体内で Shikimisäure が形成す るのはいわねる Davis-Sprinsson の機構に徒う。す なわち瞊から出発して適当な中間生成物を経るのであ るがこの中間生成物を特別にマークすることによって このことが分る。

更に J. A. Brown 及び A. C. Neish ${ }^{25)}$ 及び K. Freudenberg ${ }^{28)}$ 等の研究は Phenylbrenztraubensäure, Phenylalanin 及び Tyrosin の如き David の機棈に 含まれていない化合物を又リグニンに変化することを 示している。かかる知識の集㔍があるにるかかわらず, リグニンの構成単位の生合成にたいしてDavisの反応

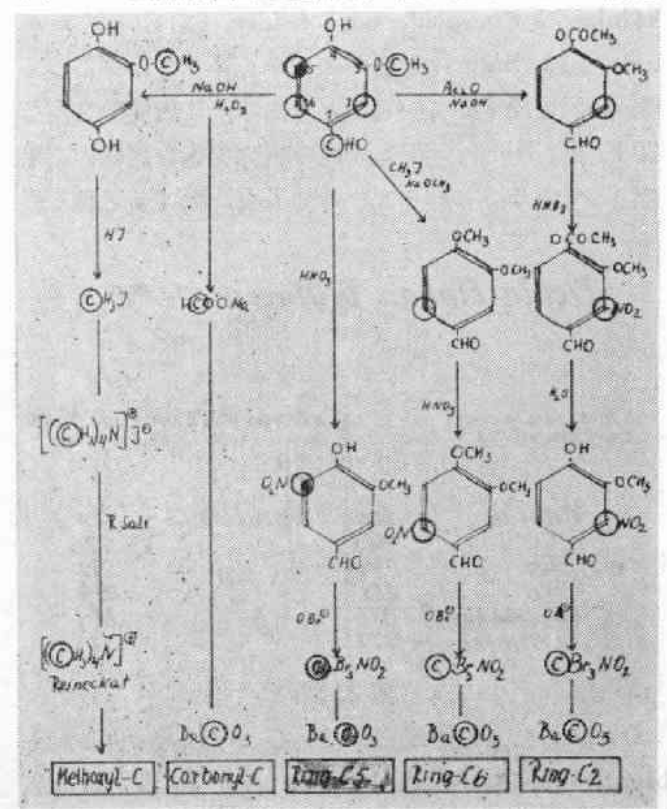

第 18 図 パニリン分子の分解
形式が有效であるか否かはまだ確かではない。特に Phenylpropane 側鋇の形成についてそ5である。こ の目的のために唐糧の小枝に D-Glukose 1-14C を注入 した。酸化によってVanillinが得られ，このVanillin 中の重要な岸素原子を定量した。カルボニル炭素は Dakin の分解により, メトキシル基の炭素はニーテ ル閏裂により, 又 2,5 及び 6 の位固の核の中の炭素は 2 又は 5-Nitrovanillin 及び 6-Nitroveratrumaldehyd の次亜臭素酸分解によって Tribromnitromethan の形 で得た。この分解の結果は図に式にして一括した。

Vanillin に格いて子 David の公式に従って 5Dehydro-shikimisäure が直接芳香核化して生じる Phenylalanin, Tyrosin, Shikimisäure, Protokatechu-
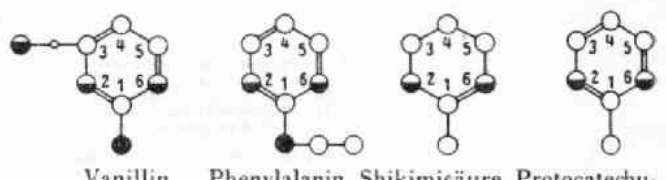

Vanillin Phenylalanin Shikimisäure ProtocatechuTyrosin säure

第 19 図

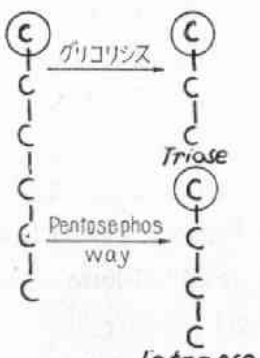

letra ose

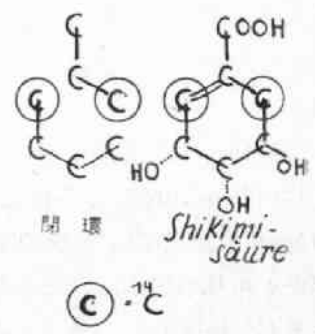

第20図 店檜における D-Glucose-1-14C の定着

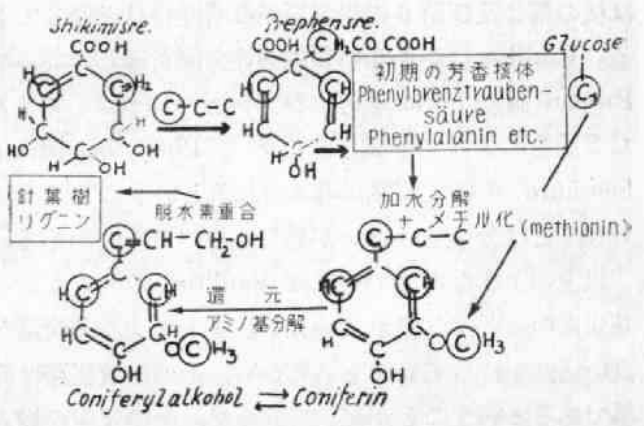

第 21 図 


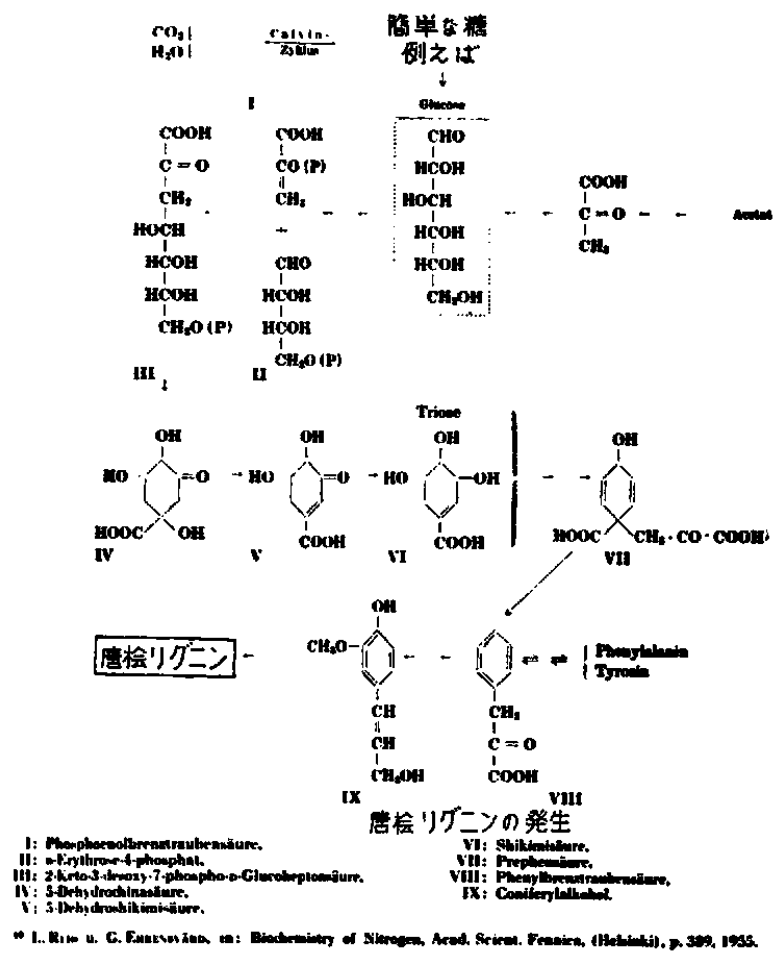

第 22 図

säure 等の場合見られるのと同様の活性分配が存在す ることは明らかである。左記の簡単にまとめた図はこ のような糖の芳香核体への移行を闹び示したあのであ る。

\section{この移行は式では上のように表わすことができる。}

Prephensäureの芳否核化，すなわち通常の Phenylpropan 化合物の生合成の際に Shikimisäure のカル ボキシル基の炭索は，この場合性不活性な炭素原了で あるが，消失してしまう。その替りに Glukose のグ リコリシス反応の結果生じた炭素 3 個の断片が入る。 この新しい炭素原子は活性をもって沏り，その大きさ は核の第 2 及び第 6 の炭素原子の活性合棓々同じであ る。Vanillin 性かかる特街的活性分配を示し, 従って

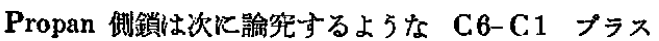
C 2 縮合によって形成され兊ない。Phenylbrenztrau・ bensäure を経て側鎖が導入されるということは，は っきりとは分っていないが恐らくその可能件がある。

以上のような考觉の中Kは Vanillin のメトキシル 基岩素のことは含まれていない。×トキシル基炭素が 高い活性を持っているところから，その構成経路は簡 単であるといらことが結論できるが, その発生の㥞式 てついて正確な官及をすることはまだいまのところて
きない。

ここでただ言及できることは, U. Bjerrum ${ }^{29)}$ が同化 作用による生成物から出発して Ribulose-5-Phosphat, Xylulose-5-Phosphat, Glykolsäure（あるい忙 Glyzerin 又は Serin）を経てメトキシルクループに至る 構成経路を提案していることである。この実験と同じ 頃 F. F. Nord 学派も同様の実冓を行い同様の結果 を出している。これら二つの結果を比較すると憼く程 良く一致している30)。

Fichte Einbau Doglucose-1. "C

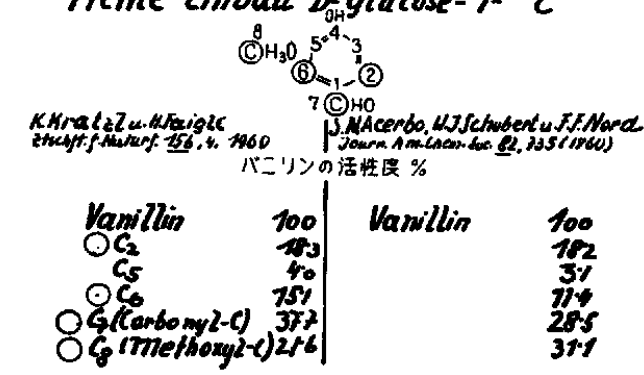

第23图

Davis の公式に挙げられている p-Hydroxyphenylbrenztraubensäure であるが，たと光 F.F. Nord が 甘蕪の作用で p-Hydroxyphenylbrenztraubensäure 
リグニン様物筫に変化する゙i) ということを示すことが できたとはいえ，高等植物に関してはこれが絶対に 必要なるのとは思えない。我々は唐㭘においては pHydroxyphenylbrenztraubensäure は実在の前駆物質 ではいことを示すことができだ22。同位元莱実験を 利用するにあたってはいかに注意梁くしなければなら ないかということを p-Hydroxyphenylbrenztraubensäure 飞よる次の実験が示している。すなわち，全く 同じ条件の下で Coniferin, p-Hydroxyhenzaldehyd 及 び p-Hydroxybenztraubensäure を注入して見る。そ の結果，次にあげた図からリグニンは強い活性を持っ

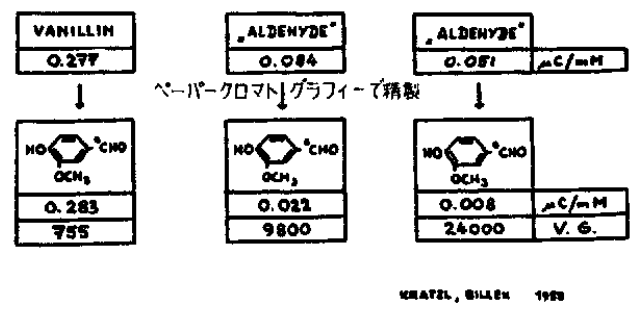

第 24 图

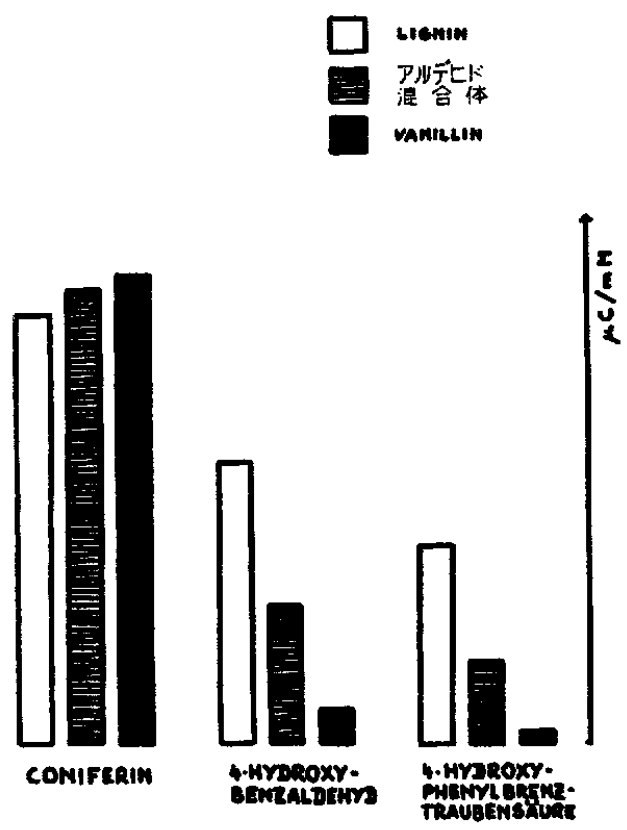

第 25 図

ており，分解して生した Aldehyd は含計すると相憗 らずかなりの活性を示している。しかし，paper一又 㤝 thinlayer chromatography 比よって定量的炏 Vanillin を分離してしまうと，p-Hydroxy 構成単位住非
常に僅かな活性を示すにすぎないことがわかる。Vanillin は唐檜リグニンの分解生成物として最す重要な 規準であるから，このような注入生成物はリグニンと 推定することはできない。A. C. Neish ${ }^{25,33,34) に 上 ~}$ って見い出された如く，このような $\mathrm{p}$-Hydroxyphenylbrenztrauben säure のリグニンへの移行は単子菜 植物に执いてのみ起る。

T. Higuchi3 ${ }^{35}$ によっても論議されたことの岁る既述 したような C.6-C1 体から C6-C3 体が形成するこ 々は二次的役割をはたすにすぎない。T. Higuchi は Arylpropan 側錤恃 C6-C1体が C2体と縮合すること によって，ひょっとすると Oxyaldehyde 及び Aceto. aldehyde の縮合によって Acetoin 構造を生成すると 想像している。ただリグニンにはかくの如き Acetoin 粠造は少なくともそのままの形では認められず（C一 $\mathrm{CH}_{3}$ グループはごく僅か存在する化すぎない）又か かる反応は叙起りそうすない。それにるかかわらす゚ 我々のグループの 2, 3 の実験がかかる反応が全く可 能であることを示している。我々は酄か汇非常に不自 然といえる前駆物筫，すなわち Kreosol をとのメチ ル基をマークしてで注入した。唐㭘の小枝は Kreosol

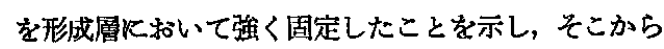
得られたりグニンは酸化すると高収率で活性 Vanillin

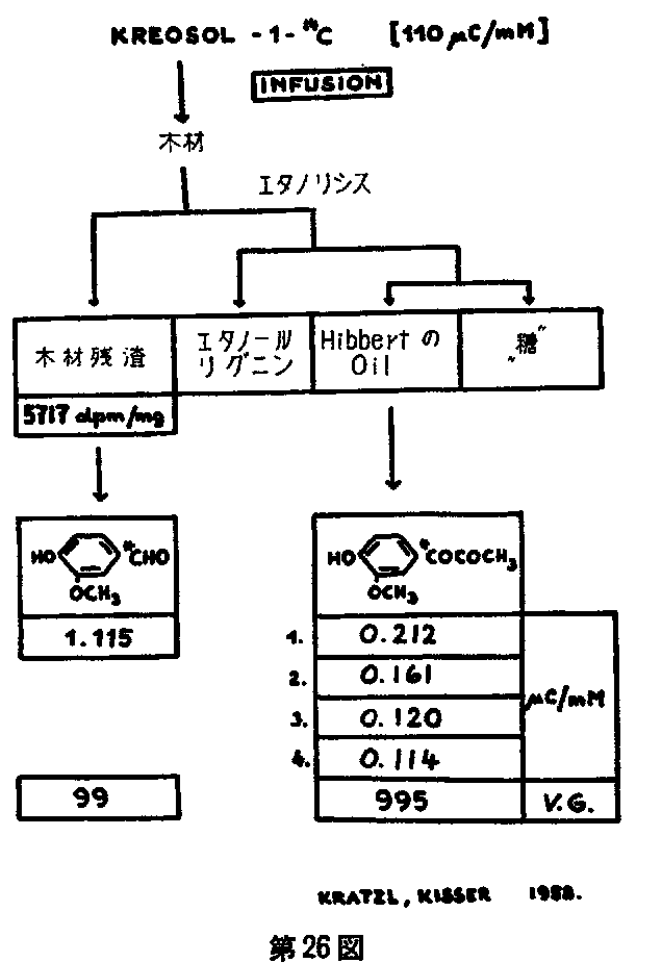


を与えた。 Kreosol は酸化すれば Vanillin を与える からこのこと自体はそう特徴的なこととはいえない。 しかし，取るに足らぬ規模であるが，エタノリシス によって Diketon 及びスルホン化及びアルカリ分解 によってVanillin と Acetaldehyd として回収され, かつ一定の同位元素含量にすることができる Arylpropan 体が得られる。従って植物には全く二次的規模で はあるがC6-C1 体プラス C 2 体がら (その物質代謝に ついてはここでは省略するが) Arylpropan 側鋇を形 成する能力があることが明らがである。 F. H. Brauns そ L. Fiedler ${ }^{37}$ は新らしい醉素を発見した。これは
Benzaldehyd と Glycin の縮合の際に触媒作用のある Phenylserinaldolose である。

$$
\begin{aligned}
& \mathrm{R}-\mathrm{CHO}+\mathrm{CH}_{2}\left(\mathrm{NH}_{2}\right)-\mathrm{COOH} \\
& \quad \longrightarrow \mathrm{R}-\mathrm{CH}(\mathrm{OH})-\mathrm{CH}\left(\mathrm{NH}_{2}\right) \cdot \mathrm{COOH}
\end{aligned}
$$

かかかる応が C1 側鎖から C 3 側鎖を形成する一つ の可能な反応形態かる知れない。

しかし，C1 プラスC2 による側鎖形成は一般的な 生化学的経路でないように思学, 不自然な前駆物質が 与えられたときに起ったすので, それる Coniferin を 注入した場合と比較して䄪 $10 \%$ 程度に過ぎない。こ の例はまとめて次の简単な式ですをととるす。

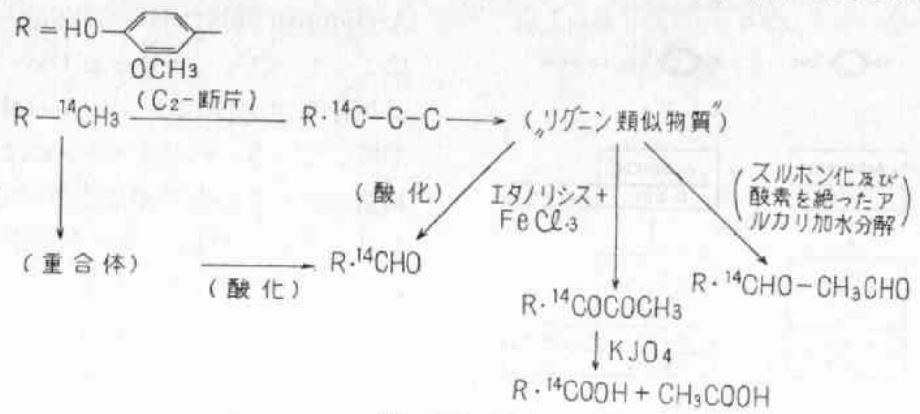

第 27 図

\section{Dünnschichtchromatographie (Thin- layerchromatography) のリグニン 分解 生成物研究への応用}

過去 2 年間に亘って, 我々 G. Puschmann 並びに H. Simon ${ }^{387}$ と共に paperchromatography と並んで特 飞 thinlayerchromatography を導入した。これは, Stahl ${ }^{309}$ 亿よって有機化合物を分離する一方法として 見出され，分析的目的のためには非常に重要であるこ とが記述されているるのである。リグニン化学に就い ては, 分解で生じた aldehyd, Hibbert の Keton 及 びその他の分解の結果生した生成物を报わなければな らない。ガラス板の上に吸着冎特に硫酸カルシウム シリカゲル etc.のサスベンジョンを用意しこれを䩐幧 する*)

かくして得られる $0.3 \mathrm{~mm}$ 程度の厚さの吸着剤の層 上に, 出発点上に混合物を約 $1 \sim 2 \mathrm{mg}$ スボットする。 このガラス板を溶媒中に浸して Thinlayerchromatography を展開する。1〜2時間という短い時間で分 離は完了する。 paperchromatography と比較した場 合, この方法の長所は特に同位元素を用いた研究の際, 比較的多量チャージできること，媒体が無機物である こと, そのため溶出が容易であること, 分崔効果が鋭 敏であること及び試料が小さいスポットとして拡がら

* Kieselgel G (Merk, Darmstadt, DBR.)
ずいるので特に Geigercounter で感し易いこと等 があげられる。又直接に autoradiography る作るこ とができる。一方短所として举げられることは分陮が

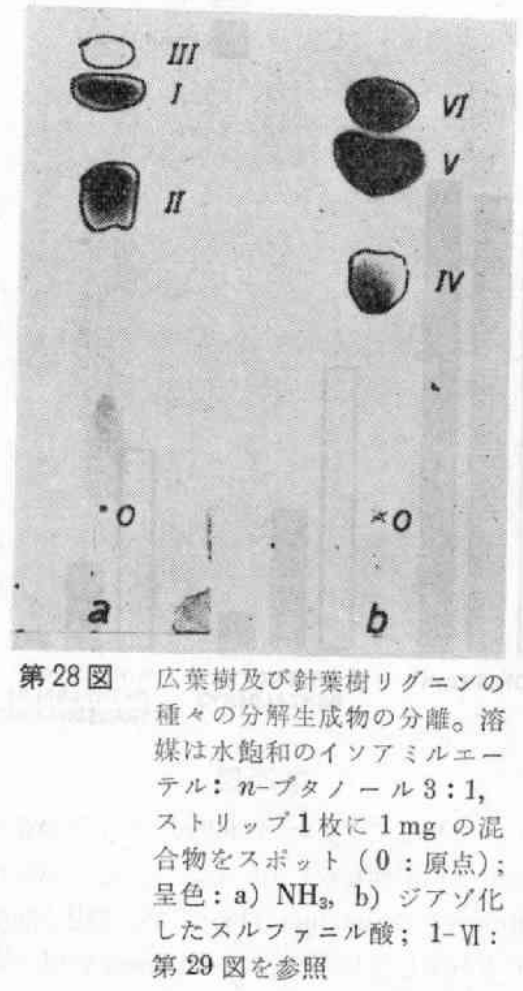


分配則汇よるのではなく吸着の法則に従って行なわれ るために一般に分離効果は paperchromatography $飞$ 少る。それです thinlayerchromatography はリグニ ン化学の中の全般の化学研究に执いて確実な利点を示 したがそのことについてはこれに関する別の論文でふ
れておいた。次節で我々 thinlayerchromatogramm を, 例えば aldehyd の分䑾(b) 及び Diketon の分離 (a) そついてのべる。

いままでに研究したリグニン分解生成物の表

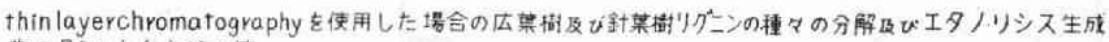
物のR十のおおよ炎の値

\begin{tabular}{|c|c|c|c|c|c|c|c|c|c|}
\hline & 化 合物 & & $z \int_{\mathrm{OH}}^{\mathrm{X}}$ & & 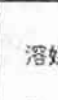 & 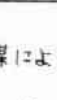 & るRf & 优 & 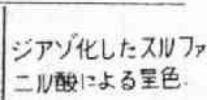 \\
\hline & & $x$ & $\mathbf{Y}$ & $z$ & A & 8 & c & D & \\
\hline $\begin{array}{r}\text { I } \\
\text { III } \\
\text { III } \\
\text { IV } \\
\text { V } \\
\text { VI } \\
\text { VII } \\
\text { VIII } \\
\text { IX } \\
\mathbf{X}\end{array}$ & $\begin{array}{l}\text { Vanilloylacetyl . } \\
\text { Syringoylacetyl } \\
\text { p-Hydroxybenzoyl-acetyl } \\
\text { Syringaaldehyd } \\
\text { Vanillin. } \\
\text { p-Hydroxybenzaldebyd } \\
\text { Syringasaure } \\
\text { Vanillinsaure } \\
\text { p-Hydroxybenzoesaure } \\
\text { Ferulasäure. }\end{array}$ & $\begin{array}{l}\mathrm{COCOCH}, \\
\mathrm{COCOCH}_{3} \\
\mathrm{COCOCH} \\
\mathrm{CHO} \\
\mathrm{CHO} \\
\mathrm{CHO} \\
\mathrm{COOH} \\
\mathrm{COOH} \\
\mathrm{COOH} \\
\mathrm{CH}=\mathrm{CH}\end{array}$ & $\begin{array}{l}\mathrm{OCH}_{3} \\
\mathrm{OCH}_{2} \\
\mathrm{H} \\
\mathrm{OCH}_{2} \\
\mathrm{OCH}_{2} \\
\mathrm{H} \\
\mathrm{OCH}_{2} \\
\mathrm{OCH}_{3} \\
\underset{\mathrm{H}}{\mathrm{OCH}}\end{array}$ & $\begin{array}{l}\underset{\mathrm{O}}{\mathrm{C}} \mathrm{H}_{2} \\
\mathrm{H} \\
\mathrm{OCH}_{\mathrm{H}} \\
\underset{\mathrm{H}}{\mathrm{H}} \\
\stackrel{\mathrm{O}}{\mathrm{H}} \mathrm{H}_{2} \\
\underset{\mathrm{H}}{\mathrm{H}}\end{array}$ & $\begin{array}{l}0,6 \\
0,39 \\
0,67 \\
0,35 \\
0,58 \\
0,67 \\
0,24 \\
0,28 \\
0,31\end{array}$ & $\begin{array}{l}0,47 \\
0,32\end{array}$ & $\begin{array}{l}0,23 \\
0,38 \\
0,48\end{array}$ & 0,41 & 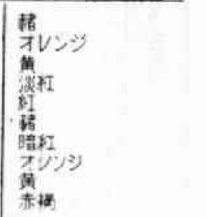 \\
\hline $\mathbf{X I}$ & Sinapinsaiure .... & $\mathrm{CH}=\stackrel{\mathrm{COOH}}{\mathrm{CH}} \underset{\mathrm{l}}{\mathrm{COOH}}$ & $\mathrm{OCH}_{2}$ & $\mathrm{OCH}$ & & & & 0,27 & 眐多 \\
\hline 溶 & $\begin{array}{l}\mathbf{A}=\text { Isoamyläther } \\
\mathbf{B}=\text { Methylenchl } \\
\mathbf{C}=\text { n-Butylizther } \\
\mathbf{D}=\text { n-Butylather }\end{array}$ & $\begin{array}{l}\text { (wassergesättig } \\
\text { orid. } \\
\text { (wassergesättig } \\
\text { (wsssergesättig }\end{array}$ & $-n-B$ & $\begin{array}{l}\text { ohol } 3: 1 . \\
\text { a:t. } \\
\text { dure to: } 1 .\end{array}$ & & & & & \\
\hline
\end{tabular}

第 29 図

最近この方法を広葉樹りグニンの形成の研究に導入 して成功を収めた。

\section{広葉樹リクニンの形成について}

K.Freudenberg ${ }^{3}$ は Sinapinalkohol はそれたとけで は脱水素重合体を与えず, 又キノン型の化合物汇酸化 されないことを示している。 K. Buchtela と我々は40) Coniferylakohol と C3 をマークしたSinapinalkohol から生成する混合重合体は広葉樹D H Pを与え, エタ ノリシスによって放射性活性の Syringoyl 構成単位 を与觉ること, 従って少くとも Syringa 構成単位の 一部ができており, ここでも又 $\beta$-Aryläther の形成 が役割を演してているとを示した。

次の赛験では ${ }^{11}$ 第 I 系列に括いて針葉樹の代表とし $て$ Fichte (トウヒ Picea excelsa) 飞 Syringin と Syringaaldehyd—これは針葉樹には非常に 不自然な

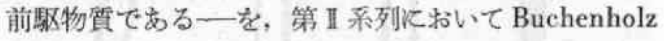
(ブナ, Fagus silvatica) 及び Flieder（ニワトコ, Syringa vulgaris) に Coniferin を与えた。これらの 物質は全部側鎖の C 3 がマークしてある。酸化する と Oxyaldehyd の混合物を, 又エタノリシスでは Diketon の混合物を与えた。次に示した thinlayerchromatogramm の図が明らかに示与よ5に Vanillin のみならず Syringaaldehyd あ活性であるのでブナ ではメトキシル化が 5 位に起っている。又, エタノリ
シスでは活性の Vanilloylacetyl と Syringoylacetyl を与える。次に示す四は, thinlayerchromatogram の 写真と Geiger counter による湘定結果を示したるの でる。

更に次の困はコントロールテストとブランクテスト

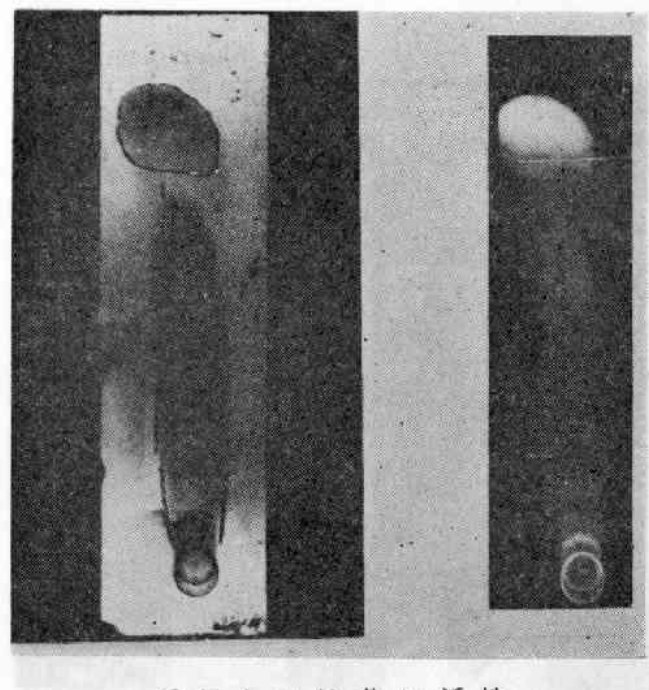

ジケトンは共に活性

第30図プナの $3^{14}$ C-Coniferin について Vanilloylacetyl ¿ Syingoylacetyl の) thinlayerchromatography $k よ$ る分離 


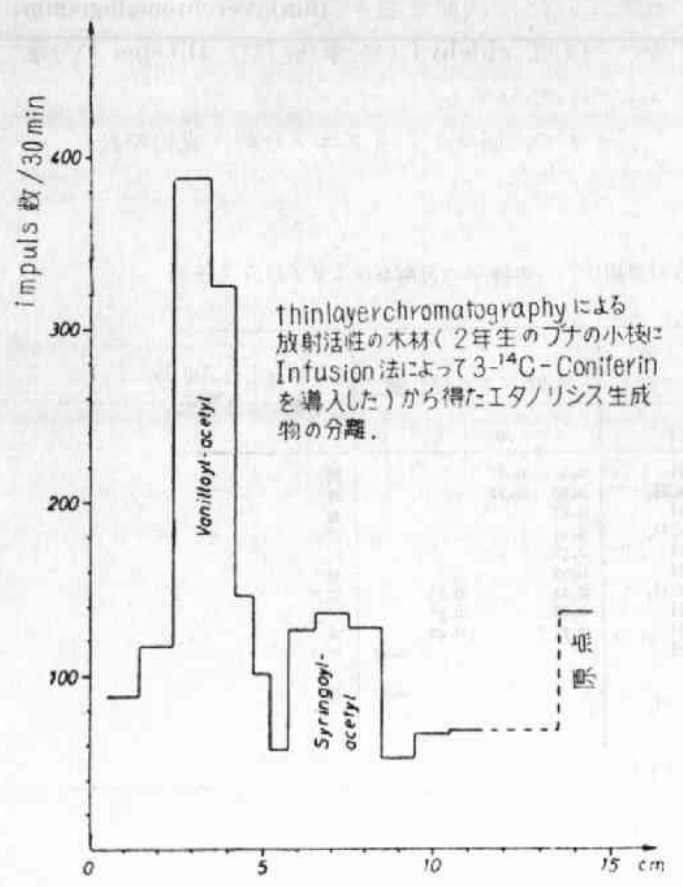

第 31 図

を表わするのであるが，放射性活性の合成して造った Vanilloylacetyl は, thinlayerchromatogramm では 全々活性の污れによる不鮮明さを示さないことが証明 された。このことが又,この方法の利点が大きいこと を意味している。

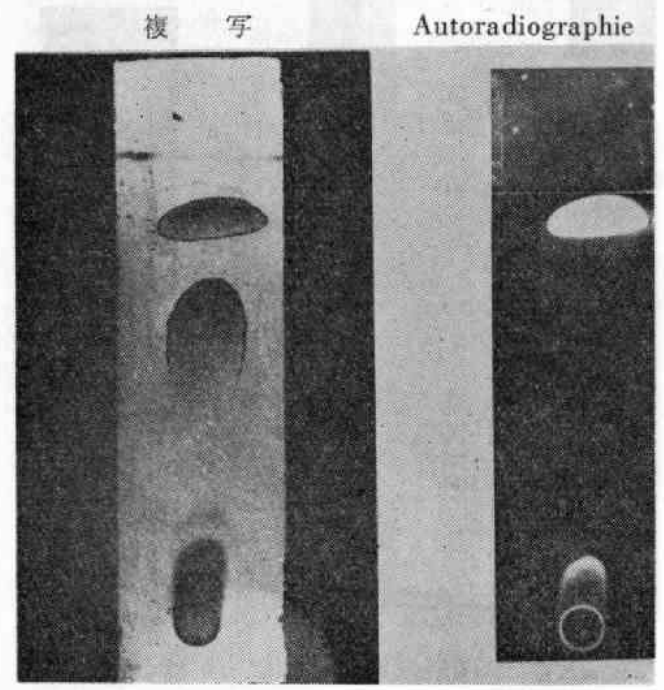

第32図 Thinlayerchromatography 活性 Vanilloylacetyl 及び不活性 Syringoylacetyl か子混合物の 分噰
しかし又，別の実験によっても，針葉樹により Syringa 構成単位が取り上げられることを示すことか゚ できる。唐桧村によって Syringin (34図) と Syringaaldehyd (35図) は明らかに形成層に取り入れられる ことを添付した autoradiography が示している。
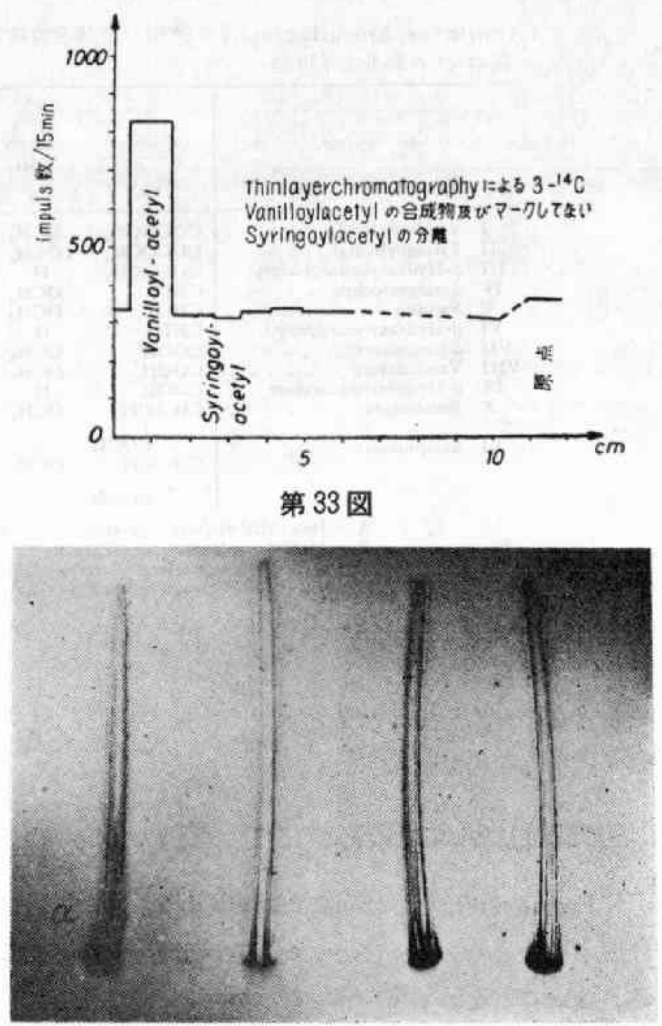

第 34 図

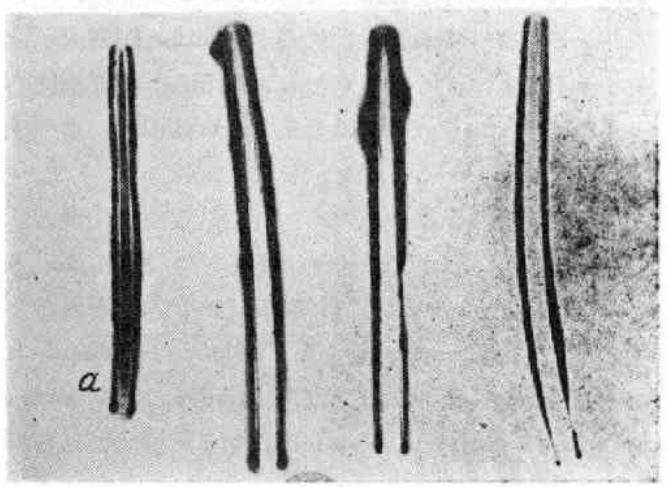

第 35 図

$\mathrm{a}=$ 未抽出

こごでも又, 分解により得られる aldehyd ばかり でなく,エタノリシスによって得られたIDiketon る 分離定量した。 


\begin{tabular}{|c|c|c|}
\hline & 物签の dpm/mg & 物叟の $\mathrm{dpm} / \mathrm{m} \mathrm{Mol}$ \\
\hline 轴出木材 & 204 & \\
\hline アルデヒド曒合物 & 427 & 74.730 \\
\hline Byringaeldehyd & 664 & 120.850 \\
\hline Pentluln & 91 & 13.840 \\
\hline
\end{tabular}

Kretzl u. Puoohnenn, 1960

\section{第 36 图}

従って, 唐梅です広葉樹りグニンに全く性質の似た 物質が作られる。怙どろくべことには両者共量的化 は大きくないが，脱メトキシルの現象が確認された。 分解 aldehyd 中活性の分配があること添激の図

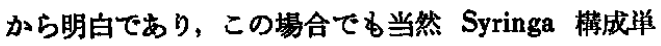
位を与充た場合に得られるVanillin が最も興味ある 物質と買えるであろう。

又, 次の図(39)加分るよ5に, この Vanillin な る判定となる生成物の同位元索含有韋を示す值が得ら れる。

私の考えでは, かかる脱メチル過程はこのような生 化学的システムでは現在まで未だ認められていない。 原理的には，唐檜材に Syringin を添加することによ $っ て$, 放射性活性の分解実験により判定した場合広葉 樹リグニンと見做すことができるような物質を周檜材 から作り屾すことが可能である。我々はちょうどいま，

\begin{tabular}{|c|c|c|}
\hline \multicolumn{3}{|c|}{ アツデヒド潛合 } \\
\hline & 物 $840 \mathrm{dpm} / \mathrm{mg}$ & 物翼の $0 \mathrm{dpm} / \mathrm{m} \mathrm{MOl}$ \\
\hline & 4.151 & 631.000 \\
\hline 第 1 分解绻 & 2.605 & 396.100 \\
\hline 犇 2 分解 & 2.160 & 328.000 \\
\hline 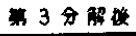 & 2.149 & 326.500 \\
\hline
\end{tabular}

Kratzl u. Puechmann, 1960

\section{第 37 图}

sarbonyl- ${ }^{14} \mathrm{C}$-syringaaldehydinfusion)

\begin{tabular}{|c|c|c|}
\hline & 物西の d pm/mg & 粼置 n $\mathrm{dpm} / \mathrm{m} \mathrm{Mol}$ \\
\hline 艘出木材 & 2.445 & \\
\hline アNンデヒド混合物 & 2.609 & 396.000 \\
\hline Van1121n & 272 & 41.340 \\
\hline
\end{tabular}

Kratzl u. Puschmann, 1960 第 38 図
唐梌 (Carbonyl- ${ }^{-14} \mathrm{C}-$ syringaalde hydinfusion)

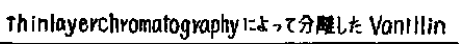

\begin{tabular}{|c|c|c|}
\hline & 物用の $\mathrm{dpm} / \mathrm{mg}$ & 物物の dpm/m Mol \\
\hline & 304 & 46.250 \\
\hline 第 1 分解後 & 275 & 41.800 \\
\hline 第 2 分解後 & 272 & 41.360 \\
\hline 第3 分解後 & 272 & 41.360 \\
\hline
\end{tabular}

Kratzl u. Puschmann, 1960 第39图

このことを，植物学的目的から不活性な Syringin を 用いて大規模に研究しょうと企てている。

植物は芳香核に種々雑多のグループや置換基る示す 多くのフェノール性物質を含有するにるかかわらず, シグニンはこの芳香核置换基に関してみると非常に平

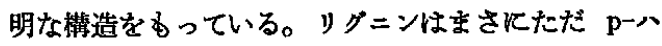
イドロキシ構成単位を持っているに過ぎず，これに1 個あるいは 2 個のメトキシル基が入っているにすぎな い。その他のグループはいずれる除外され，従ってか かるメトキシル化を生物学的䚾生ぜしめる非常侍徽 のある酵素系が存在する上うに思党る。この上うな実 験の結果からメトキシル基は時期としてはかなり早く ひょっとすると例えば Phenylalanin や Phenylbrenztrauhensäure の如き前段階の芳香体に入るるのと思 われる。まず最初作 Zimtalkohol 型 (cinnamicalcohol 梨）の側鎖をるった p-ハイドロキシ基が生ずると， 次いで, Lakase 型のごく普通の醭萦が反応して p-Hydroxycumaralkohol, Coniferyl 及び Synapinalkohol を (K. Freudenberg が示した方法で) 脱水素してり グニンとする。従って p-Hydroxy zimtalkohol の段 階はこれによってすべてのリグニンを特衟つける規準 となる反応並びにリグニンの示す諸現象がその生物学 的脱水素反応を考㝋ることにより解明されるから，中 間段階として特に必要なるのである。

大阪大学で行ったュロキュームで私はY. Kyogoku， S. Fujii 及び Y. Hachihama ${ }^{42}$ の研究について知る ことができたが，それによるとプナのリグニンでは p-ハイドロキシ構成単位がリグニンK縮合していて, 分解した場合相当する酸（例光ば Methoxytrimesinsäure) になることが証明されている。こく最近の K. Freudenberg 及び Shen-Loung-Shen ${ }^{43}$ の研究K よっても唐檜りグニンについて似たような証拋が揭げ られていて，リグニン中に約 $10 \%$ p-ハイドロキシ 柾成単位があると推定されている。 
これに相当する配糖体すなわち，p-Cumaralcohol の glucosid が本当に必要な中間段階であるか否かと いらことは未決定のままになっている。我々はむしろ これ等の配糖体は極度飞反応性のある $\mathrm{p}$-Hydroxyzimtalkohol が供給過剩になったときの一種の保管物 質でありこれが細胞液へ流れ出て木化の際注は Glukosidase により分解されて Alkohol が生成し, これがリグニン形成に使用されるという考え方に傾い ている。しかし本質的な中間段階といえば p-Hydroxyzimtalkohol 及び Coniferylalkohol あるい性 Synapinalkohol のよらなメトキシル置換基をるった誘 導体である(あるいはこれらの配糖体)。

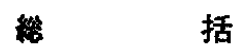

ソグニンの発生任関する Wien ク゚ループの同位元 紫を用いた研究について記述した。

そこで芳香族の前殹物賀及び分解生成物の合成を示 し，活性のリグニンより一定の分解生戌物を得るため の微量分析法を示した。尚又，特にェタノリシスと リグニンスルホン酸のアルカリ分解を抜崒記述した

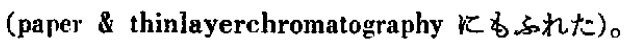

そこでまず第一に構造の定まったいくつかの Phenylpropan 体を非離し， Freudenberg の埋論が正し いことをホしこのことが Heidelberg 学派の in

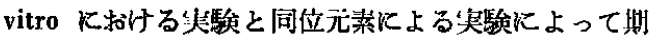
待できることを示した。定量的洞位元素のバランス が成立ち、义，個々の炭素原「の動きを怨めることに よっていかなる活性の污れる起らないことを確めるこ とができた。

側鎖の構造については $\mathrm{C} 6-\mathrm{C} 1+\mathrm{C} 2$ の絴路が副收 応としてではあるが特色つけられた。

高等植物比执いては劳香族物質がいか心して生成す るかという疑問化たいして Glucose-1-14 C を注入し た。唐恰では Glucose-1-14 C は Vanillin に分解し得 るリダニンを与え，この Vanillin の主要な炭素原子 定量的決定した（すなわち，活性の収支を求め た)。そこで高等植物纪関する David の公式が哃明で きた。F.F. Nord のグループによってる特を同じく して同様な笑験が行なわれ，比較してみると意外な程： よく一致している。Prephensäure を経る側鎖の形成 そついて検討し，更にメトキシル化る調べた。異種の 芳香族の前聑物質（例之ば唐檜にたいして Syringin） を用いた注入法 (Infusion) による実験は，植物がメ トキシル化，脱メトキシル化を起しそれてよってリグ ニン様の物質を合成する力があることを标した。橮 化に関係のある酵素の特異性についてこれ等の色々の
実験をすとにして考察を誠みた。

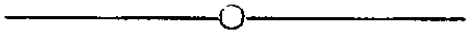

本講演内容を翻訳するにあたり，瑟切御指導下さ った当研究所三川礼博士汇深く感謝致します（訳者）。

\section{引用文 韵}

1) K. Kratzl und G. Billek, "Biochemistry of Wood" Pergamon Press London 1959

2) H. Erdtmann, Biochem. z. 258, (172) 1933 Liebigs Annalen 503, 283 (1933)

3) K. Freudenberg, Angew. Chem. 68, 84 (1956) K. Freudenberg, Fortschritte der Chemie org. Naturstoffe B 11,43 (1954)

K. Freudenberg, H. Reznik, W. Fuchs u. M. Reichert, Naturwissenschaften 42, 29 (1955) K. Freudenberg, Journal of Prakt. Chemie 10, 220 (1960)

4) K. Freudenberg und H. Bittner, Chem. Ber. 86, 155 (1953)

5) K. Kratzl und G. Billek, Mh. (Chemie 84, 406 (1953)

6) K. Kratz] und G. Billek, Holzforschung VII 66 (1953)

7) K. Kratz], Alstracts of Papers VII Int. Congress of Pure and Applied Chem. Stockholm 1953 s 253 Holzforschung 4, 123 (1953)

K. Kratzl und (:. Billek Ml. Chemie 85, 845 (1951)

K. Kratzl und G. Billek, Holzforschung 10, 161 (1956)

K. Kratzl und G. Billek, Tappi 40, 269 (1957)

8) G. Billek u. F. E. Herrmann Mh. Chemie. 88, 735 (1958)

9) H. Silbernagel, Mh. Chemie 86, 256 (1955)

10) K. Kratzl, Mh. Chemie 78, 173 (1948)

K. Kratzl, Österr. Chem. Ztg. 49, 144 (1948)

K. Kratzl und F. Rettenbacher Mh. Chemie 80, 622 (1949)

11) A. v. Wacek, K. Kratzl, u. A. v. Bezard, Ber. 75, 1346 (1942)

A. v. Wacek u. K. Kratzl, Journ. Polym. Sc. 3, 539 (1948)

K. Kratzl, Ber. 76, 895 (1943) 77, 717 (1944)

K. Kratzl u. H. Daubner, Ber. 77, 516 (1944)

K. Kratzl, Experentiy 1, 469 (1946) 
K. Kratzl u. I. Khautz Mh. Chemie 78, 376 (1948) 78, 392 (1948) 78, 406 (1948)

K. Kratzl Mh. Chemie 80, 313 (1949)

K. Kratzl u. I. Keller, Mh. Chemie 83, 197 (1952) 83, 205 (1952)

12) S. A. Brown u. A. Neish, Can. J. Biochem Phys. 32, 170 (1954)

S. A. Brown u. A. Neish, Can. J. Biochem Phys. 33, 948 (1955)

S. A. Brown u. A. Neish, Can. J. Biochem Phys. 34, 769 (1956)

S. A. Brownu D. Wright Can. J. Biochem Phys. 36, 1037 (1958)

S. A. Brown u. D Wright, Nature 175,688 (1955)

A. Neish, Canad. Jour. Bot. 36, 649 (1958)

13) K. Kratzl u. H. Faigle, Mh. Chemie 90, 768 (1959)

14) Dissertation K. Buchtela Universität Wien 1957

15) K. Kratzl und W. Schweers, Mh. Chemie

85, 1046 (1954)

85, 1166 (1954)

K. Kratzl, G. Billek und W. Schweers,

Referatenband d. XIVth Int. Congress für reine $u$. angew. Chemie, Zürich 1957 Seite 377

K. Kratzl u. W. Schweers, (ihen. Ber, 89, 186 (1956)

K. Kratzl, Mikrochemica Arta 1956, 159

16) K. Kratzl u. G. Billek, E. KIein u. K. Buchtela Mh. Chemie 88, 721 (1957)

K. Kratzl u. E. Klein Mh. Chemie 86, 848 (1955)

K. Kratzl, G. Billek, A. Graf, G. Hofhauer, N, K. Buchtela und e. Klein, Angw. Chemie 68, 384 (1956)

Österr. Chemiker Ztg. 57, 9 (1956)

17) K. Kratzl und P. Claus, unveröffentlicht

18) T. Higuchi, Jour. of Biochemistry 45,675 (1958)

19) K. Kratzl u. G. Hofbauer

Mh. Chem. 87, 617 (1956)

Mh. Chem. 89, 96 (1958)

20) E. Adler u. S. Yllner, Svensk Papperstidn 57, 78 (1954)
E. Adler u. S. Yllner, Acta Chem. Scand. 7, 570 (1953)

E. Adler u. K. J. Björquist, Acta Chem. Scand. 5, 211 (1951)

E. Adler B.O. Lindgren u. V. Saeden, Svensk Papperstidn 55, 245 (1952)

siehe auch unter 1.) Zusammenfassung $E$. Adler, Seite 137

21) L. Mitchell u.H. Hibbert, J. Amer. Chem. Soc. 66,602 (1944)

22) K. Kratzl, W. Kisser, J. Gratzl u. H. Silbernagel, Mh. Chemie, 90, 771 (1959)

23) O. Goldschmidt, Tappi 38, 728 (1955)

24) K. Freudenberg 5 th World Congress of Forestry, Seattle 1960 Abstr. of Papers GP/105/VI/C

K. Freudenberg u. M. Friedman B 93, 2138

K. Freudenberg u. B. Lehmann B 93, 1354 (1960)

K. Freudenberg u. A. Sakakibara, Liebigs Annalen 623, 129 (1959)

25) A. C. Neish, An. Review of Plant Physiol. 11, 55 (1960)

26) D. R. Mac Calla u. A. C. Neish, Can. I. Bioch. and Phys. 37, 537 (1959)

27) F. F. Nordu u. J. Schurert, 5 th World Congress of Forestry, Seattle 1960, Abstr. of Papers GR/56/VI/C:

G. Eherhard u. W. J. Schubert, J. Amer. Chem. Soc. 78, 2835 (1956)

28) K. Freudenberg, Angw. Chem. 68 (1956)

K. Freudenberg u. F.Niedercorn, B 91, 591 (1958)

29) R. L. Hamill, R. U. Byerrum u. C. D. Ball, J. biol.Chemistry 224, 713 (1957)

30) W. Schubert u. S. N. Ascerbo, Archiv of Biochem. and Biophys. 83, 178 (1959)

31) S. N. Ascerbo, W. J. Schubert u. F. F. Nord, J. Amer. Chem. Soc. 80, 1990 (1959)

32) G. Billek in 1) Seite 207 K. Kratzl u. G. Billek, Mh. Chemie 90, 536 (1959)

G. Billek u. E. E. Herrmann, Mh. Chemie 90 , 89 (1952)

33) A. C. Neish in 1) Seite 213

34) S. A. Brown, D. Wright und A. C. Neish, Can. J. Biochem. and Phys. 37, 25 (1959) 
35) T. Higuchi in 1) Seite 161

Phys. Plant 10, 633 (1957)

36) K. Kratzl, W. Kisser, A. Graf und G. Hofbauer, Mh. Chemie 90, 526 (1959)

K. Kratzl, G. Billek, A. Graf und W. Schweers, Mh. Chemie 87, 60 (1956)

37) F. H. Bruns und L. Fiedler, Nature 181, 1533 (1958)

38) K. Kratzl und G. Puschmann, Holzforschung 14, 1 (1960)

H. Simon, Dissertation Universität Wien 1960

39) E. Stahl, Pharmacie 11, 63 (1956)

E. Stahl, Chemikerzgt. 82, 323 (1958)
E. Stahl, Parümerie u. Kosmetik 39, 564 (1958)

H. Grisebach und N. Doerr, Naturwissenseh. 17, 514 (1959)

G. Machata, Wiener Klin. Wochenschrift 71, 301 (1959)

40) K. Kratzl und K. Buchtela, Mh. Chemie 90, 1 (1959)

41) K. Kratzl, Tappi 43, 650 (1960)

42) Y. Kyogoku, S. Fujii und Y. Hachihama, Privat Mitteilung.

43) K. Freudenberg und Shen-Loung-Shen, B 97, 2533 (1960)

\section{クヌート・グスタフソン・ハムステン氏}

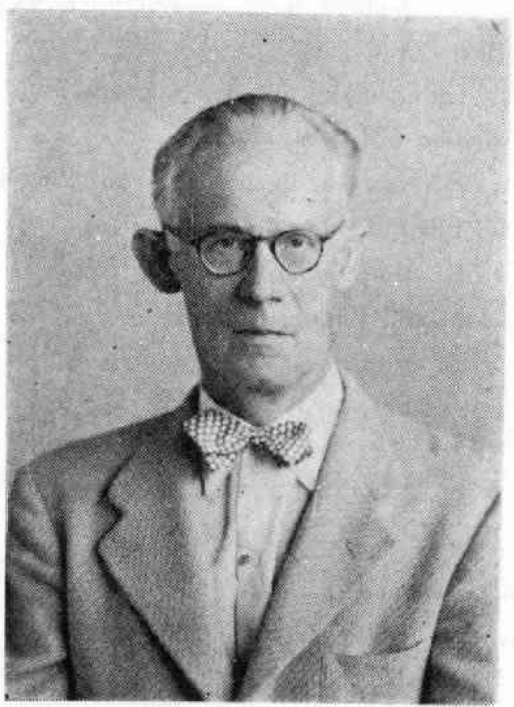

クヌート・グスタフソン・ハムステン氏は丁度一生 淮の半 36 年間を日本に湴在したが，このたび株式会 社ガデリウス尚会を引退し 6 月 26 日, 日本を去って スウェーデンに慅国した。

ハムステン氏は北は北海道, 南は九州に至る迄日本 中の製紙工場にはよく知られている。信頼性強く疲れ を知らないサーピス振りは全く賞嗼の外はない。遠近 を問わず御得意先よりサーピスの要求があった場合八 ムステン氏は何時でも心よく引き受けてすぐ出かけて 行っだ。同氏にとっては寝台や座席を得ることは間題 ではなく, 唯次の列車の出発時間を間合わすことであ った。

明沿44年スウェーデンで工学技術の学位を獲得した
八ムステン氏は同国サラ機械工場の製図工としてスタ 一トをきったが, 大正 6 年ルーツ・アキュムレーター 会社に入社して，この会社を日本で代理している株式 全社ガデリウス商会に 9 カ月間技術援助を与える目的 で炤和元年来朝した。それが 36 年に亘る長年月とな ったのである。昭和 6 年ハムステン氏はガデリウス商

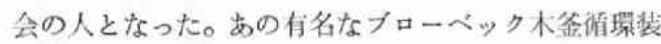
㯰はハムステン氏の活躍と巧妙なサービスの御蕵でH 本のパルプ工紫に拉いて久くことのできないすのとな った。このプローベック装置の 72 台以上が同氏の指

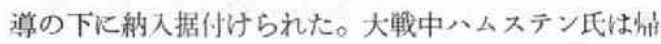
国せずに至る所で日本国内のパルブ工場にサーピス上: の注言を与えてその生産を援助した。

ハムステン氏は大戦後直らに㷌国したが休も間も無 く, デファイプレーター会社の特別使命を带びて北米 合咅国に赴き 3 力年を過した。その後仏国政府のクラ フトパルブ及び製紙工場の組立運転猎督のためアフリ カに行った。

昭和 26 年には再度ガデリウス商会のために働くた め来朝した。大戦後この十年間にハムステン氏は日本 工業界の若い人達にるよく知られ，その真摰な貴重な 存在が認められた。

今やグスタフソン・ハムステン氏は䱋国して日ふの 活動より静かな老後の生活に入られんとしている。日 本における数多くの友人達はハムステン氏がスウェー デンで老後を健勝に偷快にまた幸福に過す様にと祈っ ている。必要な場合安眠をとることも忘れて自己の仕 事に尽瘁した健康な力強い技術者の典型であり, 又立 派な紳士でるあるグスタフソン・ハムステン氏の事は 多くの日本の紆パルプ関係の技術者によって長く記憶 されるであるう。

(ガデリニース滴会提供) 